\title{
Impact of COVID-19 on Nepali Migrant Workers and Social Safety Schemes at Destination
}

Padma Prasad Khatiwada, $\mathrm{PhD}^{1}$

Department of Population Studies, Tribhuvan University, Nepal

Corresponding email: padmapd70@gmail.com

DOI: https://doi.org/10.3126/jsp.v1i0.38208

\section{A R T I C L E I N F O}

Article history:

Received 04 Nov. 2020

Accepted 01 Dec. 2020

Keywords:

Challenges

COVID-19

Migrant workers

Social security scheme

Vulnerabilities

\section{A B $\mathbf{S}$ T R A C T}

The Coronavirus disease (COVID-19) has had an enormous impact 1 on Nepali migrant workers. By 15 September 2020, altogether 63,347 people returned home via rescue flights coordinated by the Government of Nepal. It is estimated that about 200,000 Nepalese are waiting to be repatriated. This article first examines the status of, and challenges and vulnerabilities faced by, Nepali migrant workers in the context of COVID-19. It then highlights the social security schemes offered by different countries of destination for the migrant workers. Key finding suggests that most of the migrant workers had low educational backgrounds. They had experienced changes in working hours after COVID-19. Although different safety measures were adopted at the workplace, they were largely insufficient, while on the other hand, the local residents in the destination countries treated the migrants negatively. Moreover, the destination countries were found to be giving less attention towards the social security schemes for the migrant workers.

\section{Introduction}

The Coronavirus disease (COVID-19) has brought about unprecedented crises in human mobility and foreign labour migration, which is regarded as one of the key global economic and social activities supporting livelihoods of millions of families. The estimated number of international migrants in the world is 272 million, which equates to 3.5 per cent of the global population (IOM, 2020).

Migration in Nepal, which is a main pillar of the national and household economy, has also been severely affected both positively and negatively due to the COVID-19 pandemic (IOM, 2019). Estimates show that the number of migrant workers

1 This paper is based on the rapid phone survey entitled STATUS OF NEPALI MIGRANT WORKERS IN RELATION TO COVID-19 conducted by the International Organization for Migration (IOM) Nepal Office. The author worked for this survey as the Team Leader and is privileged to use the output data and facts used in this report for non-financial purpose. 
currently at work in foreign countries ranges from 2.4 million to 3 million. In 2018/19, major countries of destination for Nepali migrants included Qatar (31.8\%), United Arab Emirates (26.5\%), Saudi Arabia (19.5\%) and Kuwait (6.8\%) (MOLESS, 2020). These are also the countries where job cuts have been witnessed due to the impact of COVID-19. The Foreign Employment Board of Nepal estimated that about half a million migrant workers would return from Gulf Cooperation Council (GCC) and Malaysia soon after the lockdown is lifted. The Government has decided to repatriate about 25,000 Nepali migrants living in vulnerable condition in various countries based on priorities. About 200,000 Nepali migrant workers in India are reported to have returned to Nepal just before the country declared a national lockdown on 24 March 2020. The Ministry of Home Affairs has reported 700,000 migrants to have returned home from India during the lockdown, with thousands stranded at the Nepal-India border.

The COVID-19 pandemic has also put a halt in the process of migration of aspirant migrants. There are about 115,000 aspirant migrants who have taken labour permits from the Government but have not been able to fly out (DOFE, 2020). The entire migration process of 328,681 aspirant migrants, who had taken pre-approvals, has been put in halt. Similarly, the pandemic has severely affected the employment of migrants in countries of destination as well. COVID-19 has created serious problems on those migrants who are undocumented, domestic workers, workers whose contractual period is finished and those who were already in exploitative situation during the migration process (NHRC, 2020).

The crisis in labour migration has consequences on the remittance inflow - the main economic lifeline for Nepal's national and household economy. Nepal received Nepalese Rupees (NRs) 879 billion, which is equivalent to about 25.4 per cent contribution to the country's Gross Domestic
Product (GDP) (IOM, 2019). There are still uncertainties as to what level of magnitude would the remittance inflow drop, but it is certain that it will decline. For example, the Asian Development Bank (ADB) has estimated that Nepal may see 28.7 per cent contraction in the overall remittance in 2020 , highest among the developing Asia (ADB, 2020). But Nepal Rastra Bank, Nepal's central bank, has estimated that remittance inflow may not contract by such a large rate. The estimates show that remittance could drop by about 15 per cent. This estimate is comparatively less than the World Bank's estimate of 20 per cent decline (World Bank, 2020). Despite these differing estimates, the global pandemic has pushed the already vulnerable migrants and their families further into deeper poverty. Most of them are returning empty-handed due to wage theft with nothing but a few personal belongings and the prospects of falling further into debt and poverty (Migrant Forum in Asia, 2020). Other problems they are facing include discrimination in conduct, inadequate quarantine facility, non-payment of salary, wage cut, layoff, and remain stranded. The major reasons for migrant workers to return range from completion of contract period, job loss, voluntary return, amnesty granted by countries of destination to the undocumented migrants, among others.

In response to the safety and security of migrant workers, the Government of Nepal has developed guidelines for the repatriation of migrants living in vulnerable conditions and reintegration of the returnee migrants. These have also been highlighted as Government priorities in the periodic plans and labour policies. For example, Nepal's Fifteenth Periodic Plan (2019/20-2023/24) has aimed at making foreign employment safe, respectable, free from exploitation at every stage of migration and resulting into maximum benefits. For this, bilateral agreements between countries, labour diplomacy and coordination between all 
stakeholders, including non-resident Nepali associations, have been emphasised. Even for the protection of migrants traveling to India, local governments are required to register them for the facilities of insurance and welfare funds (NPC, 2015). The Government has two main policies to deal with migrant workers - National Labour Policy 2014 and Foreign Employment Policy 2012. These policies aim at promotion of employment opportunities within the country and an end to compulsion to migrate overseas for work, protection of labour in countries of destination and reducing their risks and vulnerabilities.

The Government's repatriation policy, as highlighted in the "repatriation guidelines", is focused on providing financial support to the stranded Nepalese, working abroad. As per the guidelines, for workers who have not received air tickets to return home and other expenses from their host country, the employer or the recruiting agency shall be entitled to provide financial support. The Government will use the Foreign Employment Welfare Fund for this purpose. As of 30 July 2020, 5,000 Nepali workers applied for support to return home. Initiation has also been made to repatriate 413 Nepali workers in detention centres in Malaysia, Saudi Arabia and Bahrain (The Kathmandu Post, 2020). Nepali missions abroad are verifying applicants' status before recommending their names to the Government as recipients of airfares. Despite this policy, the Government has not yet set the timeline for repatriation and apparently might take some time. The Government has allocated NRs 750 million for repatriating Nepali migrant workers migrating through legal channels following the contribution to the welfare fund. Employers of nearly 20,000 Nepali workers in various countries have agreed to pay for their air ticket after they were laid off amid the COVID-19 crises. The Government has also emphasised that the companies who lay off their workers will require paying the airfare for their return. In such circumstances, the Government can play a pivotal role to provide support and guidance to migrant workers (IOM, 2020).

Until the third week of August 2020, a total of 52,251 people have returned to the country through flights, even though it was estimated that over 200,000 Nepalese were in dire need of immediate rescue (CCMC, 2020). There is also no record of major layoffs in many countries as it was reported in various media. Initially, reports came out that nearly 20 per cent or 280,000 of the Nepali migrant workers abroad were at risk of losing their jobs because of the pandemic.

With due attention to the need for reintegration of returnee migrants, the Government announced to create 700,000 jobs during the annual budget of Fiscal Year (FY) 2020/21. Likewise, the Government has allocated NRs 4.34 billion to provide trainings to support the returnee migrants, mainly working in informal sectors and the new labour force that enter in the market. These returnees and those who would not be able to migrate for work need support so that they can find or create employment. In this context, it is important to understand their current status, their plans once they return home and their expectations from the Government. It is for such an understanding that this survey has been conducted so that the support to be provided by the Government and other agencies matches the interests and expectations of the migrant workers affected by the pandemic that would eventually support in their effective recovery and reintegration.

This paper is an outcome of the rapid assessment undertaken to understand the conditions of the migrant workers, especially in relation to their vulnerabilities, intention of their return, labour rights and social protection mechanism, changes in social perception, priority work sector upon their return, reintegration plan and the sector 
of work that the migrants are/were engaged in. Three groups of migrants were considered for the purpose of this assessment: current migrants (the migrants who are still in countries of destination, including India, GCC countries and Malaysia); returnee migrants; and aspirant migrants (the migrants who have received final labour approval but are waiting for lockdown to be lifted to migrate upon the confirmation of their respective employers).

\section{Methods and Materials}

This paper is based on a survey carried out by the International Organization for Migration (IOM), Nepal. The survey was completed over a two weeks period, commencing from 30 June to 15 July 2020, under the leadership of the author of this paper. The survey mainly adopted a quantitative approach to data collection, which were cross-verified through desk reviews. Two methods - purposive sampling at the first stage, and randomisation among the selected population - were employed to ensure the representation of respondents from different backgrounds.

To select the sample size, recorded migrant workers data were collected from the Ministry of Labour, Employment and Social Security (MOLESS, 2020). These data were cross-checked with the census data accessed from the Central Bureau of Statistics (CBS, 2012). The total sample size was maintained at 3,000. Of those interviewed, 501 were current migrants residing in GCC countries, Malaysia, India and other countries; 500 were from among the aspirant group who had already taken final approvals from the Department of Foreign Employment and the remaining 1,999 were selected from a group of returnees, who had been back home from GCC countries, Malaysia, India and other countries. The respondents in each group were selected purposively.

In the case of returnees, the name list was prepared based on the records available at the holding centres in Kathmandu, immigration office, concerned provincial offices, District Administration Offices, concerned local governments, and different networks and organisations, namely National Network for Safe migration, NEEDS Nepal (for the case of returnees in Sudur Paschim), Pravasi Nepali Coordination Committee, Pourakhi Nepal, and Non-Resident Nepali Association.

Structured questionnaires (separate for each group) were prepared and were administered by experienced interviewers following a pre-test. The questionnaires covered current situation of jobs, benefits, health care and safety measures and the issues pertinent to human rights. Likewise, expectations of migrants in terms of their reintegration through support for employment and income generation were also covered.

Experienced telephone interviewers were assigned for this purpose so that the migrants would feel comfortable to respond to the questions and share their experiences. The survey was based on telephone conversation with the returnees, aspirant and current migrants (mostly living in GCC, Malaysia and India). However, some of the respondents also included those currently working in Japan, the Republic of Korea and Macao Special Administrative Region, and China.

The collected data were cleaned and edited and again converted to SPSS and STATA for analysis. The required tables, charts and graphs were generated in line with the objectives of the study by adopting bivariate and multivariate analysis approach.

\section{Results and Discussion}

\subsection{Origin country}

\subsubsection{General situation of labour migration from Nepal}

Around 500,000 people enter Nepal's labour market annually (CBS, 2019). Foreign 
migration and workers related data are collected and made available by the Central Bureau of Statistics (CBS), Department of Foreign Employment (DOFE) and Ministry of Health and Population (MOHP) in Nepal and updated and analysed by the United Nations (UN) agencies like the International Organisation for Migration (IOM), International Labour Organization (ILO), universities and research institutes. CBS collects these data through national census as well as periodical surveys like Nepal Labour Force Survey (NLFS), Nepal Living Standard Survey (NLSS) and Demographic and Health Survey (DHS). The 2011 census on population and housing showed that almost 50 per cent of Nepal's households had a member who was either working overseas or had returned. While this labour migration has a significant positive effect on Nepal's economy, it also has a series of socio-economic impacts on the welfare of Nepali nationals and their communities. Exploitation of migrant workers is rife and aspiring labour migrants too often find themselves in a situation of irregular migration or trafficking (IOM, 2019).

The DoFE, under the MoLESS, is a key source of information on labour migration as it issues and records labour permits to migrants wishing to emigrate for employment. The data however has several limitations. Firstly, it comprises only the number of labour permits issued by the Government; importantly therefore, the large number of Nepalese who go to India are not recorded. As mentioned above, the terms of the 1950 Friendship Treaty mean that no labour permits are required for Nepalese wishing to migrate to India for employment. Secondly, by only indicating the number of permits issued, the figures cannot show whether one individual has received multiple permits or cases where permits may have been issued but then not used. The DoFE issued 4,099,926 labour permits between 2008/2009 and $2018 / 2019$ that comprised of $3,888,035$ males and 211,891 females (MOLE). The labour permits issued for foreign migrant workers in decreasing trend as per the recent dataset. In FY 2018/2019, DoFE issued 236,211 labour permits, compared to 354,082 in FY 2017/2018 (IOM, 2019). The DoFE issued $4,099,926$ labour permits between 2008/2009 and 2018/2019 that comprised of 3,888,035 males and 211,891 females (DOFE, 2019).

Historically, Nepali migrant workers searched wage earning jobs mainly in India, however starting from the mid-1980s, Nepalese also started to migrate to the Gulf States and Malaysia for work. This resulted in an increase in migrant workers as well as in a proliferation of labour recruitment agencies and brokers. The decentralisation of passport issuance in Nepal also facilitated the migration of many unskilled and semi-skilled Nepalese. During the past two decades, Nepal has also witnessed an increase in the number of Nepali women seeking work abroad and being gradually recognised as important economic actors. The risk of exploitation and abuse of women migrant workers is high, particularly in largely unregulated sectors such as domestic work. The Government has put in place a series of measures seeking to protect the women migrants. To date, these measures have met with limited success and there is still evidence that many women migrants are in situations of risk. The process to be followed for Nepalese to migrate for employment is rather complex and can be time-consuming, which has spurred increase of recruitment agencies. It also means that many migrant workers use irregular channels to access foreign employment, not following the process of obtaining a labour permit (IOM, 2019).

\subsubsection{Demographic characteristics of migrants}

In the sample, about 10 per cent of the interviewees were females and 90 per cent were males. The proportion of female in 
the sample ranged from 8 per cent (current migrants) to 15 per cent (aspirant migrants). Among the returnee migrants, about 10 per cent were females (Table 1). This gender ratio in the sample is consistent with the whole population of migrants in Nepal. Nepal has witnessed an increase in the number of female migrants and is gradually being recognised as important economic actors. However, the proportion of females in total migrant

Table 1: Percentage of survey respondents by background characteristics

\begin{tabular}{|c|c|c|c|c|c|c|c|c|}
\hline \multirow{2}{*}{ Characteristics } & \multicolumn{2}{|c|}{$\begin{array}{c}\text { Current } \\
\text { Migrants }\end{array}$} & \multicolumn{2}{|c|}{ Returnee Migrants } & \multicolumn{2}{|c|}{ Aspirant migrants } & \multicolumn{2}{|c|}{ Total } \\
\hline & $\mathrm{N}$ & $\begin{array}{l}\text { per } \\
\text { cent }\end{array}$ & $\mathrm{N}$ & per cent & $\mathrm{N}$ & per cent & $\mathrm{N}$ & per cent \\
\hline \multicolumn{9}{|l|}{ Gender } \\
\hline Male & 462 & 92.22 & 1808 & 90.45 & 424 & 84.80 & 2694 & 89.80 \\
\hline Female & 39 & 7.78 & 191 & 9.55 & 76 & 15.20 & 306 & 10.20 \\
\hline \multicolumn{9}{|l|}{ Age } \\
\hline$<19$ Years & 2 & 0.40 & 125 & 6.25 & 11 & 2.20 & 138 & 4.60 \\
\hline $20-24$ & 40 & 7.98 & 494 & 24.71 & 164 & 32.80 & 698 & 23.27 \\
\hline $25-29$ & 114 & 22.75 & 502 & 25.11 & 144 & 28.80 & 760 & 25.33 \\
\hline $30-34$ & 129 & 25.75 & 366 & 18.31 & 98 & 19.60 & 593 & 19.77 \\
\hline $35-39$ & 105 & 20.96 & 249 & 12.46 & 56 & 11.20 & 410 & 13.67 \\
\hline $40-44$ & 72 & 14.37 & 154 & 7.70 & 17 & 3.40 & 243 & 8.10 \\
\hline 45 and Above & 39 & 7.78 & 109 & 5.45 & 10 & 2.00 & 158 & 5.27 \\
\hline \multicolumn{9}{|l|}{ Caste/Ethnicity } \\
\hline Brahmin/Chhetri & 226 & 45.11 & 761 & 38.07 & 156 & 31.20 & 1143 & 38.10 \\
\hline Dalit & 51 & 10.18 & 502 & 25.11 & 62 & 12.40 & 615 & 20.50 \\
\hline $\begin{array}{l}\text { Indigenous } \\
\text { Nationalities }\end{array}$ & 181 & 36.13 & 557 & 27.86 & 209 & 41.80 & 947 & 31.57 \\
\hline Tharu & 11 & 2.20 & 21 & 1.05 & 16 & 3.20 & 48 & 1.60 \\
\hline Madhesi/Muslim & 28 & 5.59 & 127 & 6.35 & 41 & 8.20 & 196 & 6.53 \\
\hline Other & 4 & 0.80 & 31 & 1.55 & 16 & 3.20 & 51 & 1.70 \\
\hline \multicolumn{9}{|l|}{ Marital status } \\
\hline Married & 415 & 82.83 & 1337 & 66.88 & 337 & 67.40 & 2089 & 69.63 \\
\hline Unmarried & 74 & 14.77 & 643 & 32.17 & 161 & 32.20 & 878 & 29.27 \\
\hline Divorced & 6 & 1.20 & 6 & 0.30 & 0 & 0.00 & 12 & 0.40 \\
\hline Separated & 0 & 0.00 & 11 & 0.55 & 1 & 0.20 & 12 & 0.40 \\
\hline Widow/Widower & 6 & 1.20 & 2 & 0.10 & 1 & 0.20 & 9 & 0.30 \\
\hline \multicolumn{9}{|l|}{ Education } \\
\hline Illiterate & 14 & 2.79 & 115 & 5.75 & 12 & 2.40 & 141 & 4.70 \\
\hline $\begin{array}{l}\text { Less than } \\
\text { Primary }\end{array}$ & 21 & 4.19 & 161 & 8.05 & 29 & 5.80 & 211 & 7.03 \\
\hline Primary & 38 & 7.58 & 232 & 11.61 & 43 & 8.60 & 313 & 10.43 \\
\hline $\begin{array}{l}\text { Lower } \\
\text { Secondary }\end{array}$ & 77 & 15.37 & 653 & 32.67 & 128 & 25.60 & 858 & 28.60 \\
\hline Secondary & 140 & 27.94 & 502 & 25.11 & 162 & 32.40 & 804 & 26.80 \\
\hline Intermediate/10+ & 168 & 33.53 & 271 & 13.56 & 103 & 20.60 & 542 & 18.07 \\
\hline Bachelor & 32 & 6.39 & 59 & 2.95 & 19 & 3.80 & 110 & 3.67 \\
\hline $\begin{array}{ll}\begin{array}{l}\text { Master } \\
\text { above }\end{array} & \text { and } \\
\end{array}$ & 11 & 2.20 & 6 & 0.30 & 4 & 0.80 & 21 & 0.70 \\
\hline \multicolumn{9}{|l|}{ Province } \\
\hline Province 1 & 146 & 29.14 & 93 & 4.65 & 126 & 25.20 & 365 & 12.17 \\
\hline Province 2 & 33 & 6.59 & 268 & 13.41 & 58 & 11.60 & 359 & 11.97 \\
\hline Bagmati & 83 & 16.57 & 297 & 14.86 & 142 & 28.40 & 522 & 17.40 \\
\hline Gandaki & 141 & 28.14 & 718 & 35.92 & 68 & 13.60 & 927 & 30.90 \\
\hline Lumbini & 82 & 16.37 & 119 & 5.95 & 68 & 13.60 & 269 & 8.97 \\
\hline Karnali & 7 & 1.40 & 176 & 8.80 & 10 & 2.00 & 193 & 6.43 \\
\hline Sudur Paschim & 9 & 1.80 & 328 & 16.41 & 28 & 5.60 & 365 & 12.17 \\
\hline Total Sample Size & 501 & 100.00 & 1999 & 100.00 & 500 & 100.00 & 3000 & 100.00 \\
\hline
\end{tabular}

Source: IOM Nepal (2020). 
population is still quite low, close to nine per cent (IOM, 2019).

Among the respondents identified in the study, most of the migrants were youth. About 82 per cent of the sample respondents (92\% aspirant migrants, $80 \%$ returned migrants, $78 \%$ current migrants) were between the ages of 20 and 40. Likewise, most of the migrants $(70 \%)$ were married. A total of 83 per cent of the current migrants and 67 per cent of both the returnee migrants and the aspirant migrants were married. The proportion of migrants in other marital groups (divorced, separated, widowed) was nominal.

Among the sampled migrants overall, 38 per cent were Brahmins and Chettris, 32 per cent Janajatis, 21 per cent Dalits, seven per cent Madhesis/Muslims and two per cent Tharus. Among the current migrants, 45 per cent were Brahmins and Chettris, 36 per cent Janajatis, 10 per cent Dalits, six per cent Madhesis/ Muslims and two per cent Tharus. Among the returnee migrants, 38 per cent were Brahmins and Chettris, 28 per cent Janajatis, 25 per cent Dalits, six per cent Madhesis/Muslims and one per cent Tharus. A comparison between current and returnee migrants shows that proportionately more Dalit migrants had to return to Nepal as compared to other groups. Likewise, among the aspirant migrants, 42 per cent were Janajatis, 31 per cent Brahmins and Chettris, 12 per cent Dalits, eight per cent Madhesis/Muslims and three per cent Tharus. This gives an indication of a higher participation of Janajatis in migration in the recent times.

Most of the migrants had low educational status. A total of 78 per cent of them had attained secondary or less education; 18 per cent had intermediate (or $10+2$ ) level of education; four per cent had a bachelor's degree; and, one per cent had earned master's degree or above. Of the total respondents, five per cent migrants were illiterate and seven per cent had studied up to primary level. Among the current migrants, 58 per cent had secondary education or lower, 34 per cent had intermediate level or equivalent, six per cent had a bachelor's degree and two per cent had a master's degree or above. The same figures for returnees were 83 per cent, 21 per cent, three per cent and less than one per cent respectively. In the aspirant migrants' group, the respective figures were 75 per cent, 21 per cent, four per cent and one per cent respectively.

\subsubsection{Regional background of migrants}

In total, a large share of migrants (31\%) were from Gandaki Province, followed by Bagmati ( $17 \%$ ), Provinces 1 and 2 (12\% each), Lumbini (9\%), Karnali Province (6\%) and Sudur Paschim Province (12\%). Among current migrants, 29 per cent were from Province 1 followed by Gandaki (28\%), Bagmati (17\%), Lumbini (16\%), Karnali (1\%) and Sudur Paschim (2\%). Likewise, 36 per cent returnee migrants were from Gandaki followed by Sudur Paschim (16\%), Bagmati (15\%), Province 2 (13\%), Karnali (9\%), Province 5 (6\%) and Province 1 (5\%).

An assessment of regional background of current and returnee migrants gives an interesting picture. A large number of migrants from Province 1 seem to have stayed in countries of destination. On the other, there were more migrants in Karnali and Sudur Paschim who returned home. This could be because migrants from these two Provinces mostly go to India and returned home during the beginning of the Coronavirus pandemic in India. Likewise, the proportion of aspirant migrants was 28 per cent from Bagmati Province followed by Province 1 (25\%), Gandaki Province and Lumbini (14\% each), Province 2 (12\%), Sudur Paschim (6\%) and Karnali (2\%).

\subsubsection{Duration of stay in destination}

Nearly two-thirds (61\%) of the returnee migrants stayed in countries of destination for less than a year. On the other, about 41 per cent of current migrants worked for less than a year. The ratio of migrant respondents staying 
for more than two years was relatively lower (approximately 25\%). For almost all (99\%) who received labour permits, the duration of the contract period was 24 months.

\subsection{Destination countries}

Among the current migrants, 24 per cent were in Saudi Arabia, 22 per cent in United Arab Emirates, 21 per cent in Qatar, nine per cent in Malaysia and six per cent in India. Thailand and Kuwait shared 4 per cent each of current migrants (Figure 1). Among the returnees, half of them had returned from India, 12 per cent from Kuwait, 11 per cent from the United Arab Emirates, nine per cent from Saudi Arabia and six per cent from Malaysia. The return from India could be attributed to open borders, Nepal's geographical proximity and a huge number of seasonal migrants working in the Indian cities.

About 29 per cent aspirant migrants were prepared to go to Saudi Arabia, 26 per cent to the United Arab Emirates, 16 per cent to Malaysia, 11 per cent to Qatar and four per cent to Kuwait. Other countries included Japan (3.0\%), Bahrain (2.8\%), the Republic of Korea (1.2\%), Oman (1.0\%) and the Maldives (0.4\%).

\subsubsection{Occupational change}

Most of the current migrants were employed in service, construction and manufacturing (about 20\% each) sectors. In the production sector, eight per cent of them were employed, six per cent were serving as security personnel and five per cent as domestic help. Likewise, one per cent of them were working in agriculture. A majority (56\%) of

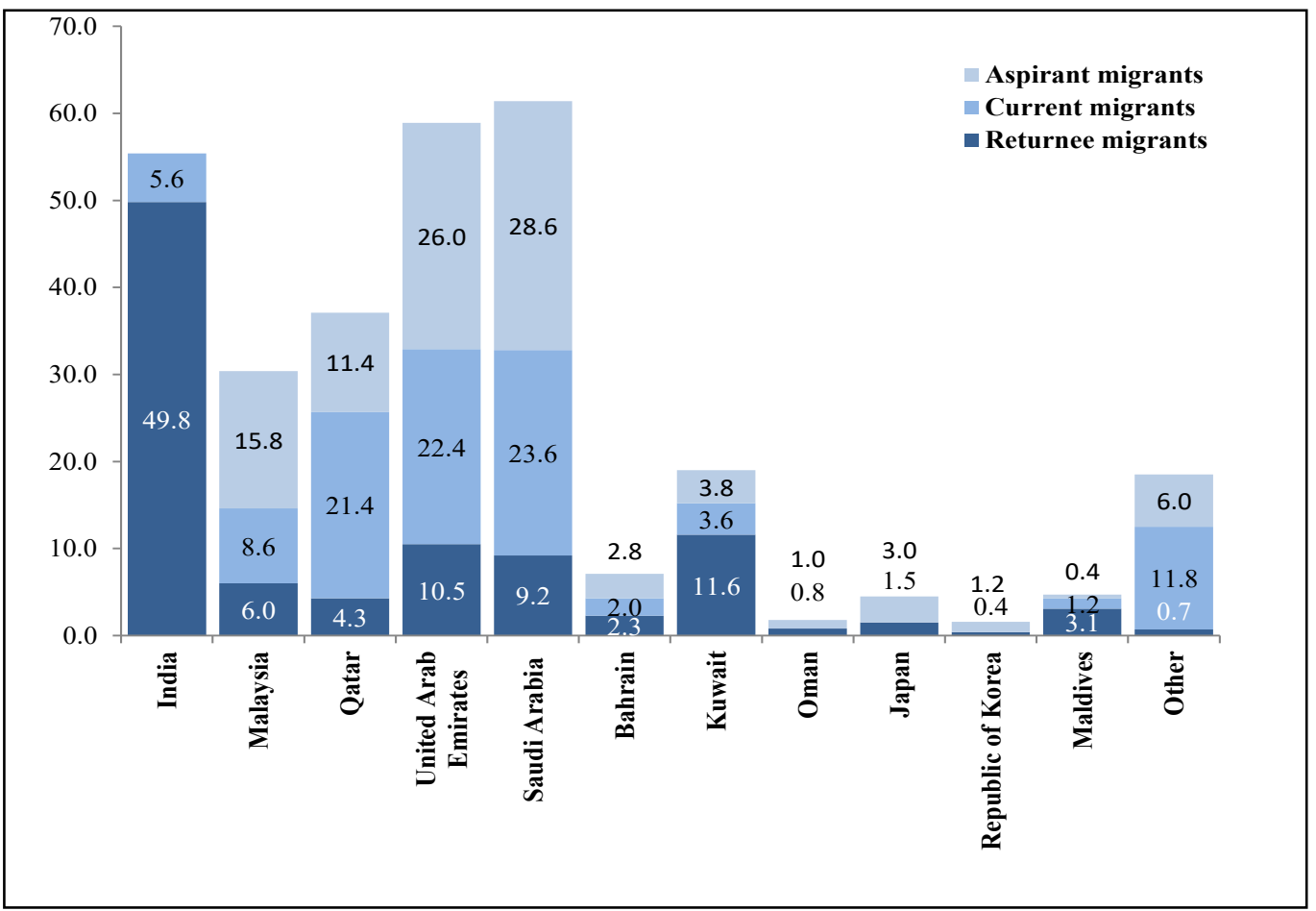

Figure 1: Percentage of migrants in destination countries

Source: IOM Nepal (2020). 
the returnee migrants were employed in the hospitality sector, followed by construction $(13 \%)$ and manufacturing $(8 \%)$. This indicates that service sector was the hardest hit due to COVID-19 resulting in job losses of Nepali migrants. Startlingly, 52 per cent of aspirant migrants had job in the service sector followed by manufacturing $(13 \%)$, production and domestic work (7\% each), security guard $(8 \%)$ and agriculture $(2 \%)$. This could also mean that aspirant migrants may not get employed in the stated occupation as 'service sector' as it seemed to be hardest hit by the crisis (Figure 2). respondents stated to be involved in those occupations, respectively. About 10 per cent were employed in services, seven per cent in manufacturing, five per cent in construction and less than one per cent in teaching.

Push factors were most crucial for the people to migrate for foreign employment. For example, about 32 per cent of thee aspirant migrants stated "poverty" and 27 per cent "unemployment" as major reasons for their migration. The other reasons stated were "to make life better" (17\%), to repay

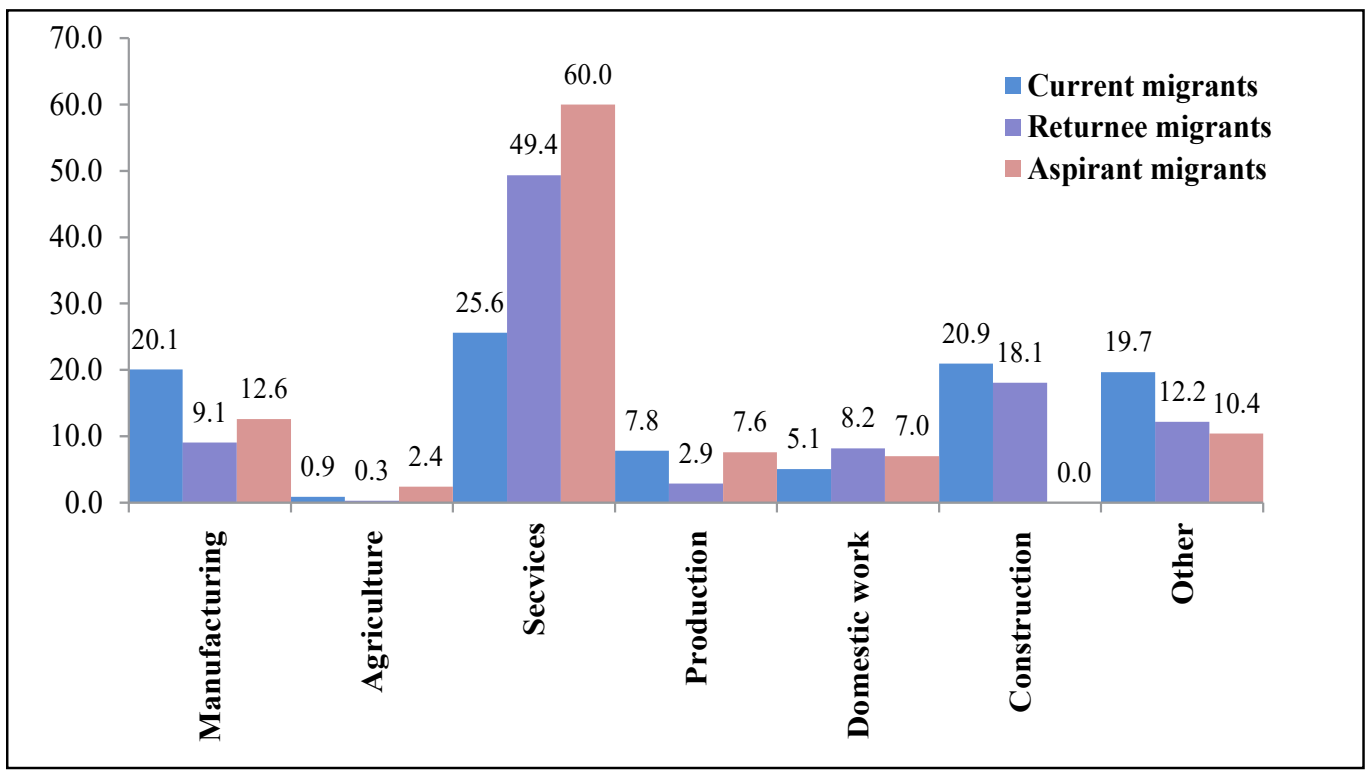

Figure 2: Occupation of migrants in different groups in destination countries

Source: IOM Nepal (2020).

\subsubsection{Current occupations in Nepal and reasons for migration}

The current occupations of aspirant migrants indicate occupational opportunities in Nepal. Agriculture and domestic works seem to employ most of the aspirant migrants because 32 per cent and 20 per cent of the loans $(11 \%)$ and to have better economic status (11\%). A few others stated family pressure and peer pressure $(0.4 \%$ and $0.2 \%$, respectively) as the reasons to migrate. Therefore, the main reason of migration was for income making. Contrary to the popular assumption, migration of youth is not seen to be induced by social reason. 


\subsection{Migration vulnerabilities and support}

\subsubsection{Impact of COVID-19 on migrants and their job status}

Almost all (98\%) migrants stated that they have been affected by COVID-19 in the countries of destination. Similarly, as stated by current migrants, the problem looms large for their job security following the COVID-19 pandemic. Even though all sampled current migrants are still in the countries of destination, about 63 per cent are at work and the remaining 37 per cent have been left without work. Some were laid off, some may re-join after a "vacation" period, and for others, the companies were closed. The job status of male and female is similar but "layoffs" were more common among female migrant workers $(26 \%)$.

\subsubsection{Source of support and change in working hours after COVID-19 in destination countries}

For the migrants who were unemployed, yet staying in countries of destination, bearing the cost of living on their own has been a big problem. Nevertheless, about 51 per cent of these migrants stated that the cost of living is borne by the company. Likewise, about 44 per cent migrants still had to support themselves, five per cent received support from friends and relatives, and 0.4 per cent from welfare agencies.

Migrants who are working in countries of destination experienced changes in working hours following the COVID-19 pandemic but most of those still in jobs have not faced a decline in working hours. This is one of the reasons why they are still working. About 66 per cent of the current migrants stated that there has been no change in their working hours whereas 28 per cent reported decrease in working hours. For those who experienced a change in working hours, a majority (54\%) said it increased by two hours and 39 per cent reported that it decreased by two hours a day (Figure 3). On an average, working hours increased by three hours and decreased by 4.4 hours.

\subsection{Regularity in payments}

A majority of current migrants $(70 \%)$ said they got regular payments. About 30 per cent

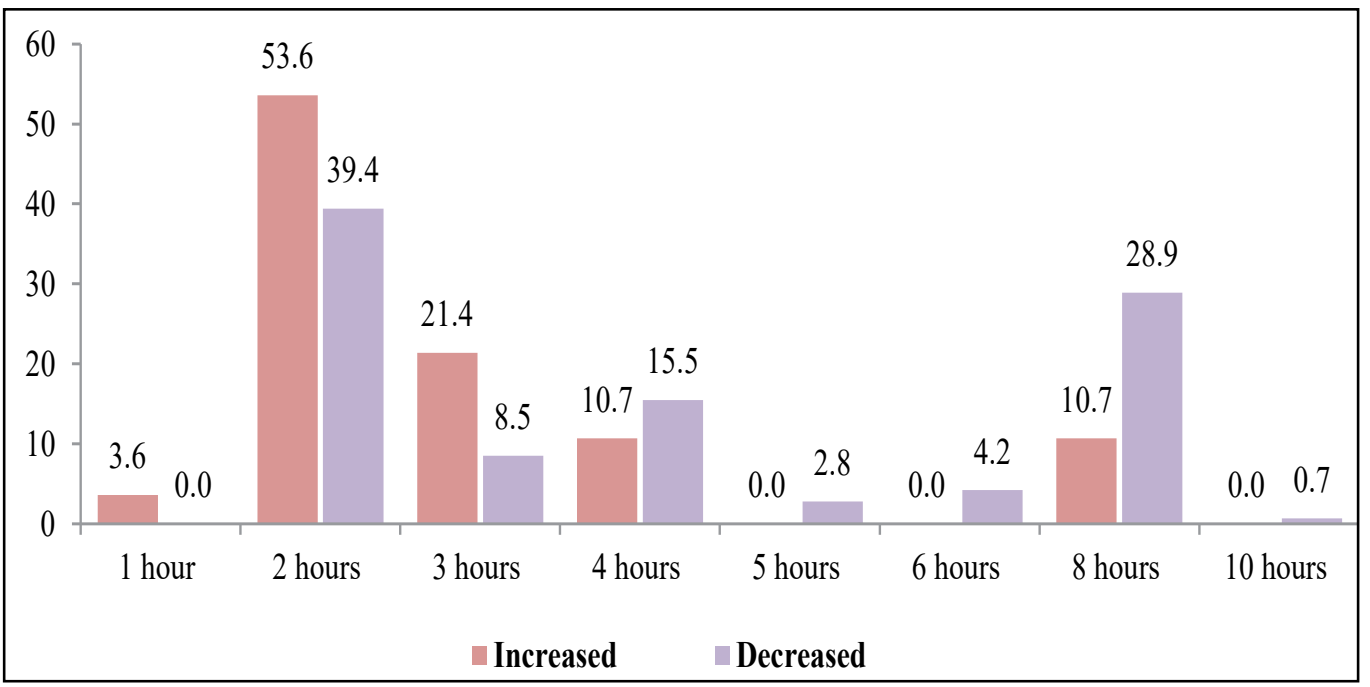

Figure 3: Change in daily working hours after COVID-19

Source: IOM Nepal (2020). 
reported that they did not get timely payments.

Higher numbers of female migrant workers did not receive a regular salary as compared to their male counterparts. More migrants engaged in domestic works did not receive regular payments as compared to other occupations. In terms of countries, more migrants (40\% to $45 \%)$ in the United Arab Emirates, Kuwait, Bahrain and Malaysia stated that they were not paid on time. Those working in formal and organised sectors were largely paid in a timely manner, but this was not the case in informal and unorganised sectors (Figure 4).

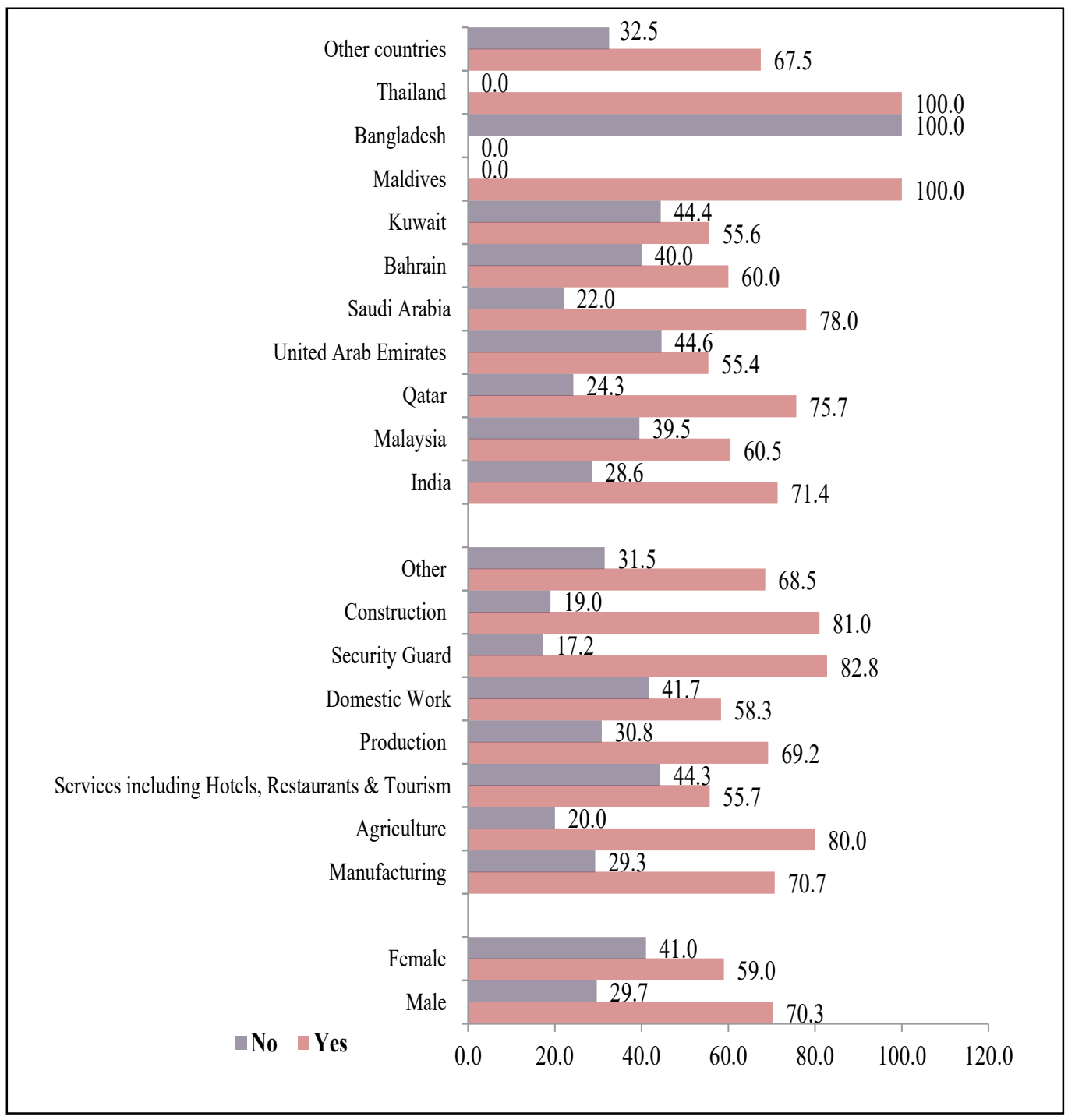

Figure 4: Regularity of salary payments by destination country, work sector and gender

Source: IOM Nepal (2020). 


\subsection{Social security scheme for current migrants}

The Government of Nepal has launched contribution-based social security scheme in 2017. This scheme is funded through the while Bahrain was identified to have better provisioning for the medical services. To conclude, Qatar, Saudi Arabia, Bahrain and the United Arab Emirates were relatively better in providing social security (Table 2 ).

Table 2: Social security schemes received by current migrants (\%)

\begin{tabular}{|l|c|c|c|c|}
\hline \multicolumn{1}{|c|}{ Country } & Insurance & Medical service & Economic support & Not at all \\
\hline India & 21.4 & 17.9 & 0.0 & 60.7 \\
\hline Malaysia & 30.2 & 16.3 & 0.0 & 53.5 \\
\hline Qatar & 30.8 & 47.7 & 0.9 & 20.6 \\
\hline United Arab Emirates & 33.9 & 17.9 & 0.0 & 48.2 \\
\hline Saudi Arabia & 29.7 & 44.9 & 1.7 & 23.7 \\
\hline Bahrain & 0.0 & 70.0 & 0.0 & 30.0 \\
\hline Kuwait & 0.0 & 11.1 & 5.6 & 83.3 \\
\hline Maldives & 100.0 & 0.0 & 0.0 & 0.0 \\
\hline Bangladesh & 0.0 & 0.0 & 0.0 & 100.0 \\
\hline Thailand & 50.0 & 38.9 & 0.0 & 11.1 \\
\hline Other & 42.5 & 15.0 & 5.0 & 37.5 \\
\hline
\end{tabular}

Source: IOM Nepal, 2020.

contributions made by the workers and the employers. During the COVID-19 pandemic, the Government is credited for disbursement of fund for the workers losing jobs during the lockdown. A similar inquiry was made with the selected respondents. Bangladesh, Kuwait, India and Malaysia were reported as the countries providing little in terms of social security coverage for migrants. Major schemes in this regard were identified as insurance, medical services and economic support. Only Maldives was identified to have provided provisioning insurance for all the migrant workers whereas Bangladesh was identified applying none of these schemes. Minor economic support was found to be applied by Saudi Arabia and Kuwait,

\subsubsection{Treatment of migrant workers in destination countries}

The majority of current and returnee migrants (70\% and $66 \%$, respectively) reported that

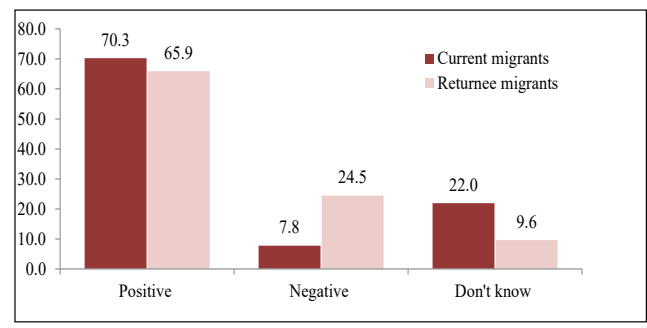

Figure 5: Treatment by locals at place of destination and home land

Source: IOM Nepal (2020). 
they were treated with respect and empathy while working in countries of destination. However, about eight per cent current migrants and about 25 per cent returnee migrants reported that they were disrespected by the local population in countries of destination. A few respondents were ambivalent over this question (Figure 5).

\subsection{Challenges faced by migrants}

In the wake of COVID-19 pandemic, migrants faced various challenges. Though about 64 per cent migrants reported that they did not experience challenges in countries of destination, other migrants said they faced various issues. One of the most pertinent challenges faced by the returnees was in terms of experiencing quarantine facilities upon their return.

\subsubsection{Problems in quarantine facilities and} local communities upon return to Nepal

Returnee migrants were asked to report on quarantine facilities upon their arrival to Nepal and the treatment they received in their local communities. About 90 per cent of the returnees stayed in quarantine facilities. Of those staying in the facilities, 85 per cent reported that it was safe. One in four $(25 \%)$ returnee migrants reported that they were not treated positively in their communities mainly because they perceived that the Coronavirus infection was taking place due to migrants. Two in three migrants reported that they were treated with respect and empathy.

\section{Conclusion}

This study examined the status of, and challenges and vulnerabilities faced by, Nepali migrants in the context of COVID-19 pandemic and supports needed for their reintegration. As is widely known, migrant workers are at the receiving front when the pandemic is raging across the globe. Demographically, most migrants were young (in the age group of 20-40 years) and married. The proportion of migrants in other marital groups (divorced, separated, widowed) was very small in size. A larger proportion of respondents were Brahmins and Chettris followed by Janajatis, Dalits, Madhesis/Muslims and Tharus. Most of the migrants had low educational status. About 78 per cent of them had obtained secondary or less education, and 18 per cent had earned the degree equivalent to Intermediate (or 10+2) level.

A comparison of regional background of current and returnee migrants gives an interesting picture. A large proportion of migrants from Province 1 seem to continue to stay in the countries of destination. On the other, there was more return migration in Karnali and Sudur Paschim provinces. This is because the migrants from these two provinces mostly go to India as daily wage labourers and returned home with the outbreak of COVID-19 pandemic.

Employment in service sector was more vulnerable than in manufacturing, which seemed more secure even at times of economic stress during the pandemic. Returnees were mostly employed in the service sector. In Nepal, agriculture seemed to be the main employment sector for most of the migrants. Push factors, mostly poverty and unemployment, were crucial for out migration, thus making employment and income generation the most important determinant for migration. Almost all migrants (98\%) were affected by COVID-19 in countries of destination. Even those current migrants faced job losses, as only about 63 per cent are at work. Other 37 per cent are laid off and are on unpaid leave. About 44 per cent migrants still had to support themselves through their savings. About five per cent of them got support from friends and relatives and 0.4 per cent received support from welfare agencies. Some migrants experienced changes in working hours after COVID-19. A total of 28 per cent migrants reported decrease but 
6 per cent reported increase in their working hours. About 30 per cent reported that they did not get regular payments.

Different safety measures were used in the workplace and 98 per cent stated that they used one or another measure. However, two per cent did not use any safety measures. The main safety measures were, in order of importance, use of sanitizers and social distancing. Safety measures also varied from country to country. Fifteen per cent respondents viewed that the safety measures were insufficient. About 25 per cent returnee migrants reported that the local population in destination countries treated them negatively.

The destination countries were identified giving less attention towards the social security schemes for the migrant workers. Comparatively, Qatar, Saudi Arabia, Bahrain and United Arab Emirates were found in better position for providing social security. One in every 10 returnees did not stay in quarantine facilities and 15 per cent of those in quarantine facilities said that it was unsafe. Similarly, one in four returnee migrants reported that they were not treated positively in their communities mainly because of the fear of COVID-19 coming with the migrants.

\section{References}

ADB. (2020). COVID-19 impact on international migration, remittances, and recipient households in developing Asia. Manila, Phillipines: Asian Development Bank. Available at https://www.adb.org/ publications/covid-19-impact-migrationremittances-asia\#: : text $=$ In $\% 20$ this $\% 20$ brief\% 2 C\% $20 A D B \% 20$ economists, immigration $\% 2 \mathrm{C} \% 20$ labor\%2C\%20and\%20health accessed on 15 October 2020.

CBS. (2012). Nepal population and housing survey. Kathmandu: Central Bureau of Statistics.
CBS. (2019). Nepal labour force survey report 2017/18. Kathmandu: Central Bureau of Statistics, Government of Nepal. Available at: http://www.https:// nepalindata.com/media/resources/ items/20/bNLFS-III_Final-Report.pdf. dofe.gov.np/ yearly.aspx accessed on 27 September 2020.

CCMC. (2020). COVID tracker. Kathmandu: COVID-19 Crisis Management Center, Government of Nepal. Available at https://www.coronatracker.com/country/ nepal/ accessed on 27 October 2020.

DOFE. (2020). Dataset on labour permission made available for the research purpose for IOM. Kathmandu: Department of Foreign Employment, Government of Nepal.

IOM Nepal. (2020). Status of Nepali migrant workers in relation of COVID -19 . Kathmandu: International Organization for Migration. Available at https://nepal. iom.int/sites/default/files/publication/ Rapid_Phone_Survey_Report.pdf accessed on 23 October 2020.

IOM. (2019). Migration in Nepal: A country profile 2019. Kathmandu: International Organization for Migration.

IOM. (2020). World migration report 2020. International Organization for Migration. Available at www.iom.int/wmr accessed on 15 July 2020.

Migrant Forum in Asia. (2020). Appeal No. 2: Urgent justice mechanism for repatriated Migrant workers now. Available at urgent-justice-mechanismfor-repatriated-migrant-workers-now accessed on 11 July 2020.

MOLESS. (2020). Nepal labour migration report 2020. Kathmandu: Ministry of Labour, Employment and Social Security, Government of Nepal.

NHRC. (2020). COVID-19 Mahamariko chapetama Nepali aapravasi sramikharuko adhikar adhyayan pratibedan, 2077 (Rights of Nepalese migrant workers amid COVID-19 pandemic). 
Kathmandu: National Human Rights Commission.

NPC. (2015). Fifteenth Periodic Plan (2019/202023/24). Kathmandu: National Planning Commission, Government of Nepal (pp. 331-332). Available at https://npc.gov. $\mathrm{np} /$ images/category/15th_Plan_Final1. pdf. accessed on 18 September 2020.

The Kathmandu Post. (2020). Nearly 5,000 Nepali workers apply to return home on government support. 7 August 2020, The Kathmandu Post. https:// tkpo.st/3ihNqZvhttps://kathmandupost. $\mathrm{com} /$ national/2020/08/07/nearly-5-000nepali-workers-apply-to-return-homeon-government-support

World Bank. (2020). Jobs diagnostic Nepal. Kathmandu: The World Bank. Available at http://documents1.worldbank.org/ curated/en/501501592797725280/pdf/ Nepal-Jobs-Diagnostic.pdf accessed on 18 October 2020. 
